\title{
NOTES
}

\section{CONSIDERATIONS IN DISCIPLINING EMPLOYEES FOR PARTICIPATION IN VIOLATIONS OF THE NO-STRIKE CLAUSE}

The year 1957 saw fewer man-hours lost through strikes than any preceding post-war year. ${ }^{\mathbf{1}}$ Nevertheless, the primary aim of management in the field of labor continues to be to eliminate or at least minimize work stoppages. $^{2}$ To do this, management must find penalties for unprotected work stoppages which will achieve the greatest deterrent force consistent with avoidance of undue prejudice to labor-management relations. Theoretically, the employer has an arsenal of remedies from which he can choose-directed against the union ${ }^{3}$ or against the individual employees who participate in the stoppage. Recent cases and publications have indicated the legal obstacles and impracticalities involved in actions against the union. ${ }^{4}$ It is the purpose of this Note to survey the contractual limitations on the employer's power to discipline individual employees for their participation in unprotected stoppages, and to suggest the considerations which should have a part in assessing the penalty.

\section{Contractual Challenges to the Employer's Disciplinary ACtion}

Basically, a concerted work stoppage is an activity "protected" by section 7 of the Taft-Hartley Act. ${ }^{5}$ An employer subjected to a protected strike can hire replacements for the strikers and need not discharge these replacements when the strikers apply for work, ${ }^{\mathbb{e}}$ but discrimination against applicants on the basis of participation or leadership in the stoppage is an unfair labor practice. ${ }^{7}$ Work stoppages lose this statutory protection under certain conditions. The most common of these is when they are in

1. N. Y. Times, Dec. 11, 1957, p. 15, col. 5.

2. TORFF, Collective Bargaining 91 (1953).

3. These include such things as a lockout, state court injunction, damage suit against the union, and contract rescission. See Daykin, Liability of Unions and Employers Under the Labor Management Relations Act, 42 IowA L. REv. 370 (1957); Ezrine, Nadir of the No-Strike Clause, 8 LAB. L.J. 769 (1957).

4. See ABA Committee on Improvement of Administration of Union-Employer Contracts, The No-Strike Clause, in ABA, PROCEEDINGS of THE SECTION ON LABOR LAw 55 (1952) (hereinafter cited as The No-Strike Clause); Chamberlain, Collective Bargainting and the Concept of Contract, 48 CoLuM. L. REv. 829, 841 (1948); Wolk \& Nix, Work Stoppage Provisions in Union Agreenents, 34 Montelly LAB. Rev. 272 (1952).
5. 49 STAT. 452 (1935), as amended, 29 U.S.C. \$ 157 (1952).
6. NLRB v. Mackay Radio \& Tel. Co., 304 U.S. 333 (1938).
7. Ibid. 
breach of a no-strike clause, ${ }^{8}$ but they are also unprotected when the dispute is arbitrable, ${ }^{9}$ when the activity is more disruptive than an ordinary strike $^{10}$ or when the activity is not directed to the common welfare of the workers. ${ }^{11}$ Most of the cases considered herein involve violations of the no-strike clause. However, the thoughts on disciplinary action will generally apply as well to other unprotected activities. Participants in unprotected stoppages may be discharged and otherwise discriminated against on the basis of their participation or leadership in the strike. ${ }^{12}$ The Act does not prevent the employer from rehiring some employees and refusing to rehire others on this basis. ${ }^{13}$

Even though the employer's disciplinary action may not be a violation of the Taft-Hartley Act, it may be subject to challenge through the grievance and arbitration procedure as a violation of the contract with the union. Two-thirds of the contracts covered in a recent survey provided for review of the employer's discipline by some form of grievance or arbitration procedure. ${ }^{14}$ Since a work stoppage could easily be used by an employer to justify discipline against objectionable union leaders or others whose real offenses lie in directions other than this work stoppage, the union must have some safeguard against these abuses. It would appear that only those contracts which expressly bar review ${ }^{15}$ should be construed to deny this challenge. It should be noted that, although the union is challenging the employer's action, when the penalty is submitted to arbitration the employer has the burden of proving that there was a violation of the no-strike clause and that the disciplined grievant participated in it. ${ }^{16}$

8 NLRB v. Sands Mfg. Co., 306 U.S. 332 (1939).

9. W. L. Meade, Inc. v. International Brotherhood of Teamsters, AFL, 217 F.2d 6 (1st Cir. 1954), cert. dismissed, 352 U.S. 802 (1956).

10. NLRB v. Fansteel Metallurgical Corp., 306 U.S. 240 (1938).

11. NLRB v. International Brotherhood of Elec. Workers, AFL, 346 U.S. 464 (1953).

12. NLRB v. Sands Mfg. Co., 306 U.S. 332 (1939).

13. The employer may have violated the act if it rehires on the basis of union as opposed to strike activity. Although employees who engage in unprotected activities themselves lose the protection of the act (NLRB v. American Mfg. Co., 203 F.2d 212 (5th Cir. 1953); Michigan Lumber Fabricators, Inc., 111 N.L.R.B. 579 (1955)) those employees who were reinstated and those in the bargaining unit who were not discharged remain protected. To discriminate against their leaders for union activity would appear to abrogate their rights under section 8 (b) (3). 49 STAT. 452 (1935), as amended, 29 U.S.C. \& 158 (a) (3) (1952).

14. BNA, ColleCtive BargatNing NEGOTIATIONS \& ConTracts 40:4 (1956) (hereinafter cited as CBNC). See Skenandoa Rayon Corp., 21 Lab. Arb. 421 (I. R. Feinberg 1953) (In this Note the name preceding date is that of arbitrator.); contract between American Air Filter Co. and United Automobile Workers, CBNC 77 :326 (1956).

15. E.g., Lever Bros,-Oil, Chemical \& Atomic Workers Int'1 Union, AFL, contract, "The Union shall not question the unqualified right of the Company to discipline or discharge employees engaged in participating in or encouraging unauthorized strikes. CBNC 51:424. Cf. Diamond Alkali Co.-District 50, UMW contract, in which the company agrees not to sue the union for damages from strikes unless the union opposes company discipline against the participants. CBNC $51: 442$.

16. McIouth Steel Corp., 24 Lab. Arb. 761 (G. E. Bowles 1955); Standard Stee1 Spring Co., 17 Lab. Arb. 423 (H. H. Platt 1951). However, the burden may be met by circumstantial evidence. Bower Roller Bearing Co., 22 Lab. Arb. 320 (G. E. Bowles 
Some contracts provide that once the arbitrator has found that the grievant participated in the stoppage he has no power to reduce the penalty imposed by management. ${ }^{17}$ Even in the absence of such a clause, a few arbitrators have held they cannot modify the penalty where the submission is merely whether the penalty was given for just cause. ${ }^{18}$ However, most conclude that they do have the power on the theory that it is necessary to make a final determination of the dispute. ${ }^{19}$ When the arbitrator assumes this power the employer must not only sustain the burden of proof as to the employee's participation, but must also justify the severity of the penalty ${ }^{20}$ and any distinction in penalty between various participants in the stoppage. ${ }^{21}$ An example of the operation of this procedure arose in McLouth Steel Corporation ${ }^{22}$ where the employer discharged two of the fifty participants in a wildcat strike. The arbitrator stated that the contract standard applied by labor-management arbitrators in reviewing differentiation of penalties was not the same as that applied by the NLRB where a finding of participation in an unprotected stoppage ends the inquiry. Rather collective bargaining contracts require a determination of relative guilt among the employees. Proof of instigation of the wildcat strike would have supported the extreme penalty of discharge, but the company failed to prove that the two grievants, though more active in the stoppage than the other participants, incited or maintained

1954) (Steward talked to men in the dressing room after which they all walked out.) ; Bethlehem Steel Co., 16 Lab. Arb. 99 (M. M. Shipman 1951) (Employee told everyone grievance meeting had been unsuccessful and walkout followed.).

17. Armstrong Tire \& Rubber Co., 18 Lab. Arb. 544 (A. E. Ralston 1952); Stewart-Warner Corp.-International Brotherhood of Elec. Workers, AFL, contract CBNC 77:326. But see United States Steel-United Steelworkers, CIO, contract, "Should it be determined by the board that an employee has been suspended or discharged for cause, the board shall not have jurisdiction to modify the degree of discipline imposed by the company; provided, however, that in a case arising out of a strike or work stoppage involving a group of employees and in which the company imposed discipline on part but not all such employees the board shall have discretion, if it finds the employees disciplined are less guilty than other employees not disciplined, to modify the penalties. ..." CBNC $51: 266$.

18. Chattanooga Box \& Lumber Co., 10 Lab. Arb. 260, 261 (W. P. McCoy 1948) ; Petro, Collective Bargaining and the Individual Employees, in NYU, EIGHTH ANNUAL CONGERENCE ON LABOR 239 (1955).

19. Underwood Glass Co., 27 Lab. Arb. 614 (J. M. Klamon 1956) ; Huntington Chair Corp., 17 Lab. Arb. 440 (R. N. Latture 1951). See Justin, Arbitrator's Authority in Disciplinary Cases, 8 ARB. J. (n.s.) 68 (1953); Platt, The Arbitration Process in the Settlement of Labor Disputes, 31 J. AM. JUD. Soc'y 54, 58 (1947). A few contracts give the arbitrator this power specifically. E.g., Fall River \& New Bedford Cotton Manufacturers Ass'n-Textile Workers, CIO, CBNC 77:326.

20. Green River Steel Co., 25 Lab. Arb. 774 (J. F. Sembower 1955) ; Fabet Corp., 12 Lab. Arb. 1126 (S. Wallen 1949).

21. Bethlehem Steel Co., 29 Lab. Arb., 635 (R. T. Seward 1957) ; Aurora Gasoline Co., 29 Lab. Arb. 495 (R. G. Howlett 1957). A few contracts confine the arbitrator's power to determining only whether the employee violated the contract. American Zine Co.-Zinc Workers Union, CIO, contract, CBNC 40:18. Compare U. S. Steel contract, supra note 17. There have also been a few cases in which arbitrators lacking power to reduce penalties have suggested that they be reduced. Colonial Provision Co., 17 Lab. Arb. 610 (M. Copelof 1951); Borg-Warner Corp., 4 Lab. Arb. 4 (C. M. Üpdegraff 1945).

22. 24 Lab. Arb. 761 (G. E. Bowles 1955). 
it. Therefore, the two were reinstated with written warnings and ten days' loss of pay.

For the most part these challenges are in the hands of the union. Although an employee may bring an unfair labor practice charge against an employer without the concurrence of the bargaining agent, ${ }^{23}$ and a few contracts provide the employee with power to take his grievance to arbitration without such concurrence, ${ }^{24}$ the employee must largely rely on the union to champion his cause. ${ }^{25}$ Since most employers are subject to union challenge by these procedures, they must abide by the contract as it is likely to be construed by an arbitrator.

\section{The Permissible Range of Penalties and the Procedures FOR THEIR IMPOSITION}

\section{A. Range of Penalties}

The evolution of contract clauses calling for penalties against individual violators of the no-strike clause has paralleled the disclaimers of union liability which followed the enactment of the Taft-Hartley Act. ${ }^{26}$ It is now estimated that more than two-fifths of the collective bargaining agreements in effect specify that individual participants may be disciplined. ${ }^{27}$ Even in the absence of such a clause the employer has this power, ${ }^{28}$ since the individual employees are bound by the agreement signed by their bargaining representative even when persuaded to violate the agreement by their union. ${ }^{29}$ The company would find little advantage in collective bargaining if the workers were not bound by these agreements. In addition, the concession of the union in agreeing to a no-strike clause will generally have been balanced by concessions made by the employer.

23. NLRB v. Kaiser Aluminum \& Chemical Corp., 217 F.2d 366 (9th Cir. 1954); Borg-Warner Corp., 4 Lab. Arb. 4, 7 (C. M. Updegraff 1945).

24. See Everett Dyers \& Cleaners, 11 Lab. Arb. 462 (A. H. Myers 1948). Contra, contracts between Central States Carriers and International Brotherhood of Teamsters, AFL, CBNC 77:301; George Groton Machine Co. and Machinists, CBNC 77:325.

25. See Anson v. Hiram Walker \& Sons, Inc., 248 F.2d 380 (7th Cir. 1957); Arsenault v. General Elec. Co., 20 Conn. Supp. 413, 137 A.2d 762 (Super. Ct. 1957). This subject has been treated in Lenhoff, The Effect of Labor Arbitration Clauses Upon the Individual, 9 ARB. J. (n.s.) 3 (1954); Note, Rights of Individual Workers in Union-Managenent Arbitration Proceedings, 66 Y YLE L.J. 946 (1957).

26. 61 STAT. 136 (1947), 29 U.S.C. \$§ 141-88 (1952). It was felt by many commentators that the amendments would make the union liable in damages even though the strike might not have been authorized. See Cox, Some Aspects of the Labor Management Relations Act, 1947, 61 HARv. L. REv. 274, 311-12 (1948) ; Note, Union Responsibility for Acts of Officers and Members Under the LMRA, 49 COLUM. L. REv. 384 (1949) (These prophesies have not been borne out. E.g., United Construction Workers v. Haislip Baking Co., 223 F.2d 872 (4th Cir. 1955), cert. denied, 350 U.S. 847 (1955).). As a result many unions were able to get stipulations against liability or at least to eliminate liability except where the strike was authorized by the union. CBNC 77:3. To replace union liability, the contracts often specified discipline against the individual participants. The No-Strike Clause 10.

27. See CBNC $77: 4$.

28. NLRB v. Sands Mfg. Co., 306 U.S. 332 (1939); Parkway Baking Co., 21 Lab. Arb. 736 (B. F. Boyer 1953).

29. Babcock \& Wilcox Co., 29 Lab. Arb. 681 (H. T. Dworkin 1957) ; Goodyear Tire \& Rubber Co., 18 Lab. Arb. 557 (W. P. McCoy 1952). 
Although many contracts provide that violation of the no-strike clause is just cause for discipline including discharge, ${ }^{30}$ some limit the employer's sanctions to lesser penalties ${ }^{31}$ such as warnings which go on the employee's record, ${ }^{32}$ layoff ${ }^{33}$ and loss of seniority..$^{34}$ In the absence of a contrary contract clause the employer is limited to these penalties and cannot assess a money penalty against the strikers. Arbitrators have held that an employer cannot reduce the base pay of workers who are on an incentive program when they stage a slowdown ${ }^{35}$ nor can he dock their holiday pay. ${ }^{36}$ A few cases have gone beyond these limits and permitted novel penalties. Thus, in $M$. Singer $\&$ Sons ${ }^{37}$ the arbitrator was asked to devise a penalty for a union-authorized refusal to cross a sister-union's picket line. He decided that money damages would lead to a regeneration of antagonism, and penalized the contract violators by requiring the employees to make up the lost production without pay. Since the strike is a violation of the contract, it would seem that the penalty should be one foreseeable by the breacher. The traditional penalties of warning, layoff, loss of seniority, and discharge have this advantage and appear to be adequate in almost all situations to deter future contract violations.

As proper industrial discipline is considered by most arbitrators to be corrective rather than punitive, the end must be to instill self-discipline in the employees. ${ }^{38}$ Discharges, therefore, are looked on with disfavor by arbitrators. Arthur M. Ross justified this position by the following reasoning:

"Both employer and employee lose when the employee is terminated. The employer must recruit and train a replacement and must often reckon with ill will on the part of the discharged employee's fellow workers, while the employee loses his seniority and all the valuable rights associated with it. Therefore, discharge should normally be invoked only as a last resort, after it has become clear that corrective means will not succeed." 39

30. Local 1113, United Elec., Radio \& Mach. Workers v. NLRB, 223 F.2d 338 (D.C. Cir. 1955), cert. denied, 350 U.S. 981 (1956); Goodyear Atomic Corp., 27 Lab. Arb. 321 (P. N. Lehoczky 1956).

31. Babcock \& Wilcox Co., 29 Lab. Arb. 681 (H. J. Dworkin 1957) ; contracts between Johns-Manville Corp. and Federal Labor Union, AFL, and between Central States Carriers and International Brotherhood of Teamsters, AFL, CBNC 77:301.

32. Outboard Marine \& Mfg. Co., 12 Lab. Arb. 488 (J. A. Lapp 1949).

33. Bethlehem Pac. Coast Steel Corp., 28 Lab. Arb. 369 (A. C. Miller 1957); International Minerals \& Chemical Corp., 28 Lab. Arb. 121 (A. R. Marshall 1956). 34. NLRB v. Marshall Car Wheel \& Foundry Co., 218 F.2d 409 (5th Cir. 1955); NLRB v. National Die Casting Co., 207 F.2d 344 (7th Cir. 1953).

35. Jacobs Mfg. Co., 29 Lab. Arb. 512 (I. B. Scheiber 1957) ; Armstrong Tire \& Rubber Co., 18 Lab. Arb. 544 (A. E. Ralston, Jr. 1952).

36. Parke, Davis \& Co., 13 Lab. Arb. 126 (H. H. Platt 1949). Contra, Fern Shoe Co., 14 Lab. Arb. 268 (J. A. C. Grant 1950).

37. 13 Lab. Arb. 533 (I. B. Sherber 1949).

38. Ross, What Happens After Reinstatement, in NATIONAL ACADEMY of ARBITRATORS, CRITICAL Issues IN LABOR ARBITration 21, 26-27 (1957) (hereinafter cited as NAA, CRITICAL ISSUES).

39. Ibid. 
A recent American Arbitration Association study yields statistics which indicate that penalties less than discharge have been upheld over twenty per cent more often than discharges. ${ }^{40}$ Although it cannot be said that the penalty of discharge will only be upheld if the offense is extremely serious, such a penalty should be used only after careful consideration.

Poorly drafted contractual limitations on allowable penalties may lead to paradoxical results in arbitration. In Sylvania Elec. Products Co. ${ }^{41}$ the only expression in the contract dealing with discipline allowed discharge for cause. In addition to a no-strike clause, the contract barred lockouts "for any reason." Two union negotiators were discharged for failure of security clearance, under orders of the Army. In order to coerce the company into placing these men in non-sensitive positions until they appealed their denials of clearance, 150 employees violated the union's no-strike pledge and left their jobs. The company asked the union president, on pain of discharge, to try to get the workers to return but he refused and was discharged. Some of the 150 returned to work, but ninety-six refused to return unless the president was also reinstated. The company discharged the ninety-six but repented when they applied for reinstatement and commuted their discharges to two-week layoffs. The arbitrator held that although the company had the right to discharge the strikers, the contract provided no right to suspend them. Characterizing the reduced discipline as a lockout, he ruled that they should be reinstated with pay back to the time their discharge was commuted. Thus the greater penalty would presumably have been acceptable, whereas the smaller was not.

To avoid encouraging discharge under contracts such as this it would seem that a penalty listed in a contract should be construed to include all lesser traditional penalties, unless the contract clearly specifies otherwise.

\section{B. Procedures for Imposition}

Some contracts contain procedures which the employer must follow before a discharge or penalty becomes effective. ${ }^{42}$ Disciplinary action which does not follow these procedures may deprive the employer of his right to impose any sanction on the strikers. For example, Trans World Airlines, Inc. ${ }^{43}$ involved a wildcat strike at the end of which the employer informed all the strikers that they had been discharged and that they would have to fill out application forms as new employees if they wished to return to their jobs. The grievance provision stated that no employee

40. Procedural and Substantive Aspects of Labor-Management Arbitration, 12 ARB. J. (n.s.) 131, 137 (1957).

41. 14 Lab. Arb. 16 (S. Sugarman 1950).

42. Procedures for discipline are spelled out in over half the contracts. CBNC $40: 18$. They include such things as warnings, notice to the union and hearings. The Armstrong Cork Co.-United Rubber, Cork, Linoleum \& Plastic Workers, CIO, contract provides that the facts are to be reviewed with the union president before discharge. CBNC $77: 325$.

43. 24 Lab. Arb. 95 (H. M. Gilden 1955). 
who had worked ninety days should be discharged without a fair hearing. The no-strike clause, in another section of the contract, stated that the employer reserved the right to discipline, including discharge, any employee taking part in a strike. The arbitrator held that all provisions of the contract had to be given weight and therefore all the employees were entitled to a hearing before discharge even though that penalty was spelled out in the contract. The result in that case, as in most cases where the employer fails to follow the contractual procedure, was that all the strikers were reinstated with seniority (albeit without back pay) since it was too late to correct the omission of a hearing. The contract in Bethlehem Steel Co. ${ }^{44}$ provided that management could suspend and later discharge any employee who violated the no-strike clause. The company was required to give the employee a hearing and a list of reasons for the discharge. After a wildcat strike, the employer took back all the participants except two men who incited it, and sent those two a statement that they were being discharged for their violation of the no-strike clause. Their discharge followed the hearing and they challenged the employer's action through arbitration. The arbitrator held that the statement of reasons limited the employer's power, and the arbitrator's power on review, to considering only those offenses particularly charged. Therefore he could not look into their individual part in the stoppage or their past record, but was limited to the fact that they participated in the stoppage. Since others who merely participated in the stoppage incurred no penalty, the results were unequal and the dischargees were reinstated.

More than half the collective bargaining agreements in effect contain some procedure which the employer must follow, so these two holdings pose an important threat to the employer's power to penalize. Such provisions were bargained for by the union, and the employer should have no right to disregard them. However, the inclusion of an arbitration clause in the contract infers that the parties do not intend to bind each other to the meticulous standards of procedure required by courts. The arbitrator should look to the purpose behind the procedure outlined in the contract; if substantial compliance in good faith by the employer has satisfied this purpose, the arbitrator should approve. It would appear that the hearing requirement in the $T W A$ case was meant to give the employee a chance to plead his past record and to minimize his part in the stoppage. This is of importance to the employee and when it is ignored the employer rightfully should lose his power of sanction. The same rationale is behind the Bethlehem Steel decision, but there the grant of a hearing and the discussion of the dischargee's part in the stoppage satisfied the aims of the procedure.

Some contracts, instead of providing steps which the employer must take before discipline, provide that discipline is to be administered jointly 
by the union and management. ${ }^{45}$ In effect, they provide for collective bargaining over penalties. ${ }^{46} \mathrm{~A}$ few others provide that the employer petition the union to punish the employee in the manner it thinks best, and allow for review by an impartial referee if the employer is not satisfied with the sanction. ${ }^{47}$ These provisions, as well as the notice and hearing procedure outlined above, seem at first glance an inordinate limitation on management's power to redress a contract violation. They may in fact benefit the employer. His need for a quick-acting deterrent against work stoppages must be balanced against his continuing need to minimize employee antagonism. In addition, if the summary penalty is challenged the company may be forced to reinstate a dischargee and even pay him for the time since his discharge, adding needless expense to the fact that the employee has escaped with no penalty whatsoever. Finally, the arbitrator's desire, conceded or not, to seek acceptability of his verdict from both sides of the table ${ }^{48}$ will more often upset a disciplinary penalty unilaterally imposed than one which has resulted from a hearing in which the employee has been allowed to defend his actions. ${ }^{49}$

\section{Loss of Right To Penalize}

The employer may lose his right to penalize the participants in the strike, either through bargaining it away via the strike settlement ${ }^{50}$ or by actions towards the strikers which amount to condonation. ${ }^{51}$ Tribunals have differed over what is required to make out a case of condonation. For example, the National Labor Relations Board has found condonation merely from the employer's efforts to convince the employees to return to work. ${ }^{62}$

45. See contract between Electric Auto-Lite Co. and United Automobile Workers, AFL, CBNC $51: 423$.

46. An elder statesman among arbitrators has suggested that this is the best way to handle the situation. Taylor, Effectuating the Labor Contract Through Arbitration (1949), in National Academy of Arbitrators, The Profession of Labor ARBITRATION 32, 33-34 (1957).

47. See contract between Prudential Ins. Co. and Insurance Agents Int'1 Union, AFL, CBNC 40:245; Pacific Maritime Ass'n and International Longshoremen's \& Warehousemen's Union, CBNC $77: 302$.

48. It has been said that the criterion of mutual acceptability has a higher priority in disciplinary actions for violation of the no-strike clause than in any other field. Taylor, Effectuating the Labor Contract Throngh Arbitration (1949), in Natronal Academy of Arbitrators, The Profession of Labor Arbitration 32 (1957).

49. There is some evidence that discipline for violations of the no-strike clause is more apt to be upheld than the average case. Holly, The Arbitration of Discharge Cases, in NAA, CRITICAL Issues 1, 14.

50. Parke, Davis \& Co., 13 Lab. Arb. 126 (H. H. Platt 1949); National Lock Co., 12 Lab. Arb. 1194 (L. A. Rader 1949).

51. E.g., NLRB v. Wallick, 198 F.2d 477 (3d Cir. 1952) (Employer continued to look upon strikers as employees.); NLRB v. E. A. Laboratories, Inc., 188 F.2d 885 (2d Cir. 1951) (Employer agreed to reinstate men who extorted money for labor peace.)

52. California Cotton Cooperative Ass'n, Ltd., 110 N.I.R.B. 1494 (1954). But cf. Administrative Ruling of NLRB Gen. Counsel, Case K-207, 37 L.R.R.M. 1316 (1956) (employer who reinstated all strikers and discharged three after a month's investigation held not to have condoned). 
The Fifth Circuit in NLRB v. Marshall Car Wheel \& Foundry Co.53 applied a more stringent standard, refusing to accede to the Board's finding of condonation where the employer told the employees he would take them back without seniority, and later discharged the strike leaders. An interesting arbitration case in this area is Glass Container Manufacturers Institute. ${ }^{54}$ Thirty-six wildcat strikers were discharged; then fourteen rehired as new employees. The company claimed it had treated them all alike-that it rehired the better ones the same way it would have chosen from thirty-six new applicants. The arbitrator held that the fourteen were never really discharged and that the company, by failing to assess the part of each in the stoppage, had condoned the stoppage and lost its right to penalize any of them.

The Marshall Car Wheel and Glass Container cases can be distinguished but both seem correct. The employer should not be held to have condoned a violation of the contract by taking back all the strikers on equal terms, and should retain for a reasonable time his right to assess a penalty based on the activities of individuals in connection with the strike. The burden of proving condonation under these circumstances should be made difficult because of the union's opportunity, when it has enough bargaining power, to get a clear condonation expressed in a strike settlement agreement. If the outcome of the strike results in the union's inability to get such a concession, tribunals should not award what could not be secured at the bargaining table. However, where the employer does single out employees for special treatment as was done in the Glass Container case, he must take the risk that if he bases his distinction on grounds not allowed by the arbitrator's construction of the contract, he will lose his right to penalize.

\section{iII. Consmerations in Imposition of Penalmies}

The importance of the employer's basing his choice of penalty on reasonable grounds arises not only from avoidance of union antagonism but also from the fact that if the penalty is not justifiable it may be rescinded by an arbitral decision.

Arbitrators hold that the labor-management contract entitles the employers to discipline strikers because the grievance program generally provides a sufficient outlet for their problems ${ }^{55}$ and because they violated

53. 218 F.2d 409 (5th Cir. 1955) ; see also NLRB v. Fansteel Metallurgical Corp., 306 U.S. 240 (1939) (Rehiring of some sitdown strikers did not amount to condonation.) ; contract between American Enka Corp. and United Textile Workers, AFL, "... [B] [Bt rehiring any such employee shall not constitute a waiver by the Corporation of its right thereafter to take the disciplinary action as hereinbefore set forth." CBNC 77:301.

54. 27 Lab. Arb. 131 (P. N. Lehoczky 1956).

55. Parkway Baking Co., 21 Lab. Arb. 736 (B. F. Boyer 1953). Working conditions and inter-union matters caused $30 \%$ of the work stoppages in the past ten years. Cass, The Relationship of Size of Firm and Strike Activity, 80 MontHLY LAB. Rev. 1310 (1957). These are the disputes which normally come within the grievance procedure. Often, the no-strike clause is not applicable to disputes which are not subject to the grievance procedure and arbitration. See CBNC 51:102-04. 
a contract they were bound to respect. ${ }^{6}$ However, many factors should be considered by the employer in assessing a penalty against an individual for participation in a work stoppage, and by an arbitrator who reviews such penalty.

\section{A. Gravity of the Stoppage}

Often contracts state that a violation of the contract should be considered just cause for discharge. ${ }^{57}$ Yet, many arbitrators consider such a provision as indicating the maximum permissible penalty and refuse to affirm a discharge for participation in a very short work stoppage. ${ }^{58}$ For example, three men were discharged for instigating a mass meeting on company time to protest the discharge of the union president in Huntington Chair Corp. ${ }^{59}$ The arbitration was held three months after their discharge and the arbitrator held that reinstatement without back pay would be a penalty more in keeping with the type of stoppage involved. Some contracts recognize this consideration by providing that the penalty of discharge shall not be available where the employee returned to work within twentyfour hours. ${ }^{60}$ Since the object of the penalty is deterrence, it would appear that the magnitude of the stoppage should be considered in assessing the penalty. If discharge is the penalty for a ten-minute stoppage, once a stoppage has begun, the employees may be encouraged to continue to use economic pressure in the hope that they can win reinstatement as part of the strike settlement. Only where they can hope for a smaller penalty will they be encouraged to end the strike early.

\section{B. Dispute Which Cansed the Stoppage}

\section{Near-Protected Activities}

In some instances the dispute which caused the stoppage is determinative of whether the activity is protected under the Taft-Hartley Act, and the employer guilty of an unfair labor practice if he penalizes the partici-

56. Ford Motor Co., Opinion A-151 (H. Shulman 1944), in SHulman \& ChamBERLATN, LABOR Relations 47, 49 (1949): "The obligation to employ this [grievance] procedure rather than the work stoppage is a solemn contractual obligation which law and honor require to be observed. To employ the stoppage when the grievance procedure is available is to abandon the contract."

57. Bethlehem Steel Co., 29 Lab. Arb. 635, 640 (R. T. Seward 1957) ; Indianapolis Water Co.-Firemen \& Oilers Union contract, CBNC 77:301; American Enka Corp.United Textile Workers, AFL, contract, CBNC $77: 301$.

58. Underwood Glass Co., 27 Lab. Arb. 614 (J. M. Klamon 1956) (twenty-fiveminute stoppage; reduced to suspension); Curtiss-Wright Corp., 20 Lab. Arb. 15 (N. S. Carroll 1952) (mass meeting; discharge reduced to suspension). But see Bethlehem Steel Co., 30 Lab. Arb. 72 (R. T. Seward 1958) (discharge for a fifteen-minute stoppage); International Harvester Co., 13 Lab. Arb. 610 (W. W. Wirtz 1949) (discharge for two leaders of a thirty-minute stoppage).

59. 17 Lab. Arb. 440 (R. N. Latture 1951).

60. E.g., Johns-Manville Corp.-Federal Labor Union, AFL, contract, CBNC 77:301. It is also correct to assess a greater penalty for a strike which is planned to cause the greatest possible damage to the employer than for a normal walkout. $C f$. NLRB v. American Mfg. Co., 203 F.2d 212 (5th Cir. 1953). 
pants. Two examples of such protected strikes are those caused by an employer's unfair labor practice ${ }^{61}$ and those caused by conditions dangerous to health or safety. ${ }^{62}$ Where these factors are present but are not sufficiently acute to make the stoppage a protected activity, the penalty should take into account the extenuating cause. For example, where the company or its agents are partly to blame for the dispute, or where its agents do not take proper steps to end it, the penalty should be less severe. ${ }^{63}$ In International Minerals \& Chemical Corp. ${ }^{64}$ the work of one union included using a bulldozer to remove a muck heap. At times the pile grew too quickly for one bulldozer to keep it under control, and there had been discussions between the union and management about the use of an outside contractor. The union protested the use of any outside workers each time it was broached. The employer consulted with the union president one morning and told him that a subcontractor was to be used to help reduce the pile. The union objected, and when the employer used the outside equipment there was a wildcat strike lasting for eight days, after which three leaders were given two-week layoffs. The arbitrator held that since the dispute was a continuing matter, the company should have made earlier efforts to settle it, and should not have acted on such short notice. Therefore, although the employees admittedly breached the nostrike clause, their penalty was reduced to a one-week suspension. ${ }^{65}$

\section{Conditional No-Strike Clauses}

Since the passage of the Taft-Hartley Act there has been an increase in the use of no-strike clauses which allow strikes when certain conditions have been met. ${ }^{66}$ Often the terms of these conditional no-strike clauses are ambiguous. For example, where the agreement calls for notice to the employer followed by a cooling-off period before stoppage of work, ${ }^{67}$ there may be a question of what constitutes notice and what days are included within the cooling-off period. ${ }^{68}$ The weight to be given good-faith com-

61. Mastro Plastics Corp. v. NLRB, 350 U.S. 270 (1956); NLRB v. Wooster Div. of Borg-Warner Corp., 236 F.2d 898 (6th Cir. 1956), cert. granted, 353 U.S. 907 (1957).

62. NLRB v. Knight Morley Corp., 251 F.2d 753 (6th Cir. 1957) ; cf. NLRB v. American Mfg. Co., 203 F.2d 212 (5th Cir. 1953).

63. Green River Steel Corp., 25 Lab. Arb. 774 (J. F. Sembower 1955) (Foreman first ordered steward home, then told him to remain.) ; Saco-Lowell Shops, 16 Lab. Arb. 311 (A. H. Myers 1950) (Superintendent promised employees they would not have to work overtime in another department, then ordered them to do so.). Butt cf. Dalmo Victor Co., 24 Lab. Arb. 33 (S. Kagel 1954) (No discipline involved; employer had refused to abide by the grievance procedure.).

64. 28 Lab. Arb. 121 (A. R. Marshall 1956).

65. The same analysis is valid for fear of health or safety. Birmingham Slag Co., 12 Lab. Arb. 56 (W. M. Hepburn 1948) (Employees were afraid to try locomotive in reverse.). But cf. Paramount Printing \& Finishing Co., 13 Lab. Arb. 143 (M. Copelof 1949) (excessive heat).

66. See CBNC $77: 1$.

67. Allis-Chalmers Mfg. Co. v. NLRB, 213 F.2d 374 (7th Cir. 1954); Iudlow Mfg. \& Sales Co. v. Textile Workers Union, CIO, 108 F. Supp. 45 (D. Del. 1952); see CBNC 77:105. 
pliance with the contract may have important ramifications under the Taft-Hartley Act. ${ }^{69}$ However, as in other areas, the standards of the Board and the courts are not necessarily adopted by the arbitrator when he is construing the contract, ${ }^{70}$ so there need be no analogous result between an unfair labor practice case and the arbitral review of penalties.

The issue of a dispute over the interpretation of an ambiguous conditional no-strike clause arose in International Harvester Co. ${ }^{71}$ Here, the no-strike clause prohibited strikes over disputes which were subject to the arbitration clause of the contract. That clause in providing for arbitration of disagreements specifically excepted disputes over the employer's actions in downgrading job classifications and disputes over the exact coverage of the arbitration clause itself. The union objected to the employer's reclassification of an established job, and, believing that the action constituted a "downgrading", attempted to enter bargaining sessions with the employer. The employer contended that his action was only a reclassification on the same level, not a "downgrading," and therefore demanded that the union submit its grievance to arbitration. The union gave the formal strike notice required by the contract and caused a work stoppage. The employer suspended the strikers for five days. Upon appeal of this punishment, the arbitrator agreed with the construction of the contract clause contended for by the employer, finding that the stoppage was in breach of the contract. However, he held that punishment was not justified since the violation was unintentional. The theory of this decision was that since a dispute as to the outer limit of the arbitration clause was not subject to arbitration, upon the employer's unilateral decision of this question, the union was left with no realistic choice but to strike. The alternatives were either to accept the employer's decision without contest or to strike, assuming the risk that an arbitrator will subsequently uphold the employer's discipline by interpreting the ambiguous language of the coverage of that clause against them. This was held to be too harsh a dilemma to force upon a bargaining agent, and therefore a good faith exception was read into the no-strike clause.

The result in this case is correct, but the reasoning appears to attempt to prove too much. It would seem that the strike in question was

68. Other clauses which may cause uncertainty are those which exempt certain disputes from the operation of the pledge, as wage renegotiations (California Cotton Cooperative Ass'n, Ltd., 110 N.L.R.B. 1494 (1954) ; Continental Can Co.-United Steelworkers, CIO, contract, CBNC $77: 101$ ), or non-arbitrable disputes (NLRB v. Wagner Iron Works, 220 F.2d 126 (7th Cir. 1955), cert. denied, 350 U.S. 981 (1956); United Elec., Radio \& Mach. Workers v. Miller Metal Products, 215 F.2d 221 (4th Cir. 1954)). Some less usual conditions include the company starting suit for money damages against the union (Cutler-Hammer Co.-International Ass'n of Machinists, AFL, CBNC 77:103) and the company employing non-union men (Ass'n of Master Painters-Brotherhood of Painters, Decorators \& Paperhangers, AFL, CBNC 77 :104).

69. E.g., if the activity is actually unprotected, the union may be liable in damages. Cuneo Press, Inc. v. Kokomo Paper Handler's Union, AFL, 235 F.2d 108 (7th Cir. 1956), cert. denied, 352 U.S. 912 (1956). And if the activity was actually protected, the employer is guilty of an unfair labor practice if he punishes the participants. NLRB v. Wagner Iron Works, 220 F.2d 126 (7th Cir. 1955), cert. denied, 350 U.S. 981 (1956).

70. See McLouth Steel Corp., 24 Lab. Arb. 761, 764 (G. E. Bowles 1955).

71. 14 Lab. Arb. 302 (R. T. Seward 1950). 
actually not in violation of the contract at all. A dispute as to the employer's downgrading a job classification was clearly not subject to arbitration, but the contract did not provide for arbitration of a disagreement as to what constituted "downgrading." Just as clearly this type of disagreement was left to traditional collective bargaining methods and the union was entirely within its rights to apply economic pressure to buttress its position. On the other hand, where a contract provides for the arbitration of disputes over the extent of the coverage of the no-strike clause, neither of the above rationales would apply. Here the union has bargained away its right to strike in exchange for an opportunity to challenge the employer's interpretation by arbitration proceedings.

\section{Non-Bargaining-Agent Strikes}

Arbitrators appear to make the least change in the levied penalty where the work stoppage is against the interests of the bargaining agent, or at least without even slight color of union condonation. That is to say the stoppage is not only sufficiently independent of the bargaining agent so that it would not be liable in damages, but also is contrary to the wishes of the bulk of the members. For purposes of discussion, these shall be called "non-bargaining-agent strikes." Even in the absence of a no-strike clause such activity has generally been held to be unprotected, and thus discipline imposed by the employer cannot result in an unfair labor practice charge. ${ }^{72}$ Arbitral decisions also seem to place this activity in a special class and, although this is seldom advanced as the reason, affirm the action of the employer with near uniformity in such situations. ${ }^{73}$ It has been indicated that penalties are frequently reduced where the stoppage is short or where the dispute has touches of employer causation or fear for health, ${ }^{74}$ but these same factors do not achieve a comparable result in non-bargainingagent strike cases. For example, in Paramount Printing \& Finishing Co., ${ }^{75}$ several employees complained of excessive heat in one of the processing rooms. The business agent told them to remain on the job, but they staged a short walkout. The employer's penalties of discharge for the leader and one-month layoffs for the others were upheld by the arbitrator. The decision places no reliance on the union's counselling against the stoppage, but other cases involving similar disputes would indicate that the penalties might well have been reduced had the union been neutral in the stoppage.

These results do not appear to be the product of less conscientious prosecution of the arbitration by the bargaining agent. Once the union has undertaken the expensive project of arbitration, it seems unlikely that it

72. NLRB v. Local 1229, International Brotherhood of Elec. Workers, AFL, 346 U.S. 464 (1953) ; NLRB v. Warner Bros. Pictures, Inc., 191 F.2d 217 (9th Cir. 1951). But see NLRB v. Nu-Car Carriers, Inc., 189 F.2d 756 (3d Cir. 1951).

73. E.g., Gardner Denver Co., 15 Lab. Arb. 829 (T. J. Morrissey 1951) ; Bethlehem Steel Co., 16 Lab. Arb. 99 (M. M. Shipman 1951).

74. See text at notes 61-65 supra.

75. 13 Lab. Arb. 143 (M. Copelof 1949). 
would drag its feet and thus lose whatever respect the winning of such a cause would give it. More likely, these results arise from the arbitrator's feeling that there is a wrong in non-bargaining-agent stoppages greater than that in other violations of the no-strike pledge. Inherent is the judgment that in addition to the employee's duty to respect the contract, there is a duty to respect the decisions and policies of the bargaining agent.

Where the employee has an alternative available within the bargaining unit, a work stoppage instituted against the employer is a dereliction worthy of greater punishment. One example is where the strike challenges the basic authority of the union to act as collective bargaining agent for the unit. ${ }^{76}$ Here the employee has an obligation to express his ideas to the other employees in the hope of swaying enough to his view so that another union can displace the incumbent as majority choice. If employees unsympathetic to the bargaining agent choose to stage a work stoppage rather than seeking their remedy by persuasion of other employees, they have not only violated their contract with the employer but have also impinged upon basic concepts of majority rule. Here also, the employees are deserving of greater punishment.

Another situation occurs where the bargaining agent is willing to champion the employee's grievance but the employee is unwilling to let the grievance procedure take its course and stages a work stoppage instead. ${ }^{77}$ In Parkway Baking Co., ${ }^{78}$ a new production schedule which had been running for a few months with the concurrence of the union required the employees to clean the ovens before they left at the end of their shift. One Friday, two men turned in their time and left without cleaning their ovens. The next day, the company notified them by telegram that they were suspended for one day. The employees called their business agent who told them he would take care of the matter and arranged a meeting with the company for the next day to discuss their suspension. That night, the two bakers picketed the bakery in protest of their layoff, stopping vital deliveries of materials and holding up production for three hours. They left only when the business agent forced them to. The employer discharged them and was upheld by the arbitrator. Even though the original walkout might not have been enough, resort to self help in disregard of the grievance procedure justified the discharge.

In the same class are those cases in which a union leader is the protagonist in a grievance and instigates a strike instead of using the grievance procedure. ${ }^{79}$ Since a union leader would generally have access to

76. NLRB v. Draper Corp., 145 F.2d 199 (4th Cir. 1944); cf. Harnischfeger Corp. v. NLRB, 207 F.2d 575 (7th Cir. 1953). But see NLRB v. Summers Fertilizer Co., 251 F.2d 514 (1st Cir. 1958) (Since union representing employees was company dominated, they were protected in striking to remove it as representative.).

77. Bethlehem Pacific Coast Steel Corp., 28 Lab. Arb. 369 (A. C. Miller 1957); Nationar Tube Co., 13 Lab. Arb. 404 (R. T. Seward 1949).

78. 21 Lab. Arb. 737 (B. F. Boyer 1953).

79. Oronite Chemical Co., 20 Lab. Arb. 875 (A. E. Ralston, Jr. 1953) ; American Brake Shoe Co., 13 Lab. Arb. 294 (J. D. Larkin 1949); cf. Borg-Warner Corp., 22 
and control over the grievance machinery, he has no basis for claiming that such a procedure would not be adequate.

These cases must be distinguished from those involving disputes where self help may be the employee's sole remedy. It seems clear that were the union unfairly to favor the interests of the majority over the minority in bargaining, the minority would have no apt remedy. A recent report pointed out the following:

"The very structure of the union compels it to represent the interests of the majority. If it fails to do so, it may be unseated by a rival union or its officers may be defeated for reelection. The more democratic the union, the more sensitive it is to the wishes of its members. However, this is itself a danger, for majority rule may be destructive of the interests of individuals or a minority, especially when there are not common but competing interests." 80

An example of such a situation appeared in the United Auto Workers, where only recently the practice of across-the-board increases, so prejudicial to the highly-paid craft workers, was discarded. ${ }^{81}$ In the same vein are stoppages which result when an individual is unfairly discriminated against by the union with reference to a grievance. ${ }^{82}$

"Grievance handling offers the Union opportunities for stubtle discriminations which do not exist in the negotiations of general rules for the future. Loyal unionists may have their grievances pressed promptly to a successful conclusion while workers who have not joined the union or who opposed the business agent in the last election find it harder to obtain favorable adjustments." 83

The general conclusion of recent publications is that the individual's access to the grievance procedure is very limited. ${ }^{84}$ Theoretically, section 9(a) of the Taft-Hartley Act ${ }^{85}$ promises him a right to raise his grievance

Lab. Arb. 589 (J. D. Larkin 1954) (discharge of chairman of grievance committee upheld after he continually refused to use the grievance procedure, saying the men would not go back to work until the dispute was settled).

80. ABA Committee on Improvement of Administration of Union-Employer Contracts, Individual Grievances, in ABA, PROCEEDINGS OF THE SECTION ON LABOR LAw 33, 41 (1954) (hereinafter cited as Individual Grievances); see Cox, Duty of Fair Representation, 2 VInLANova L. REv. 151 (1957); Note, Duty of Union to Minority Groups in the Bargaining Unit, 65 HARv. L. REv. 490 (1952).

81. See also Harnischfeger Corp. v. NLRB, 207 F.2d 575 (7th Cir. 1953) ; Armstrong Cork Co. 112 N.L.R.B. 1420 (1955); motormen's strike in the New York subway system, N.Y. Times, Dec. 11, 1957, p. 27 , col. 6.

82. Cf. H. J. Heinz Co., 16 Lab. Arb. 664 (P. N. Lehoczky 1951) ; Borg-Warner Corp., 13 Lab. Arb. 710 (C. M. Updegraff 1949).

83. Cox, Rights Under a Labor Agreement, 69 HARv. L. Rev. 601,630 (1956) ; see Dunau, Employee Participation in the Grievance Aspect of Collective Bargaining, 50 CoLUn. L. REV. 731, 759 (1950).

84. See Individual Grievances 50-69; Lenhoff, The Effect of Labor Arbitration Clauses Upon the Individual, 9 ARB. J. (n.s.) 3 (1954).

85. 61 STAT. 143 (1947), 29 U.S.C. $\$ 159$ (a) (1952): “ . . Provided, That any individual employee or a group of employees shall have the right at any time to pre- 
with management, but unions can and do avoid this by a clause in the agreement or by a waiver of the right in the application for membership. ${ }^{86}$ Even in the absence of absolute proscription the grievance procedure ends early for the individual-he cannot compel arbitration since he is not considered a party to the agreement. ${ }^{87}$ In these cases, work stoppage is the only pressure an employee can bring to bear on the union ${ }^{88}$ and the employer to compel fair treatment. Although most of these activities would be classed unprotected since they are not for the common benefit and may also be violations of the no-strike clause, the fact that the stoppage was against the interests of the bargaining agent should not be taken into account in imposing penalties.

\section{Equality of Treatment}

The employer's need and justification for penalties are limited by pragmatic considerations. If half an employer's working force were to participate in a stoppage, to discharge them or even subject them to a long layoff would often inconvenience the employer even more than those being punished. Such widespread reduction of the working force might often mean a shutdown of the whole plant. This problem has led some arbitrators to grant a freer hand to employers after a stoppage. ${ }^{89}$ For example, Goodyear Atomic Corp..$^{90}$ involved a walkout of 1,500 employees in violation of a no-strike clause. The employer gave a two-week layoff to the first forty-eight who punched out. The arbitrator upheld these penalties, saying that the company had to take disciplinary action and had to take it with a small group or the plant would shut down. He therefore approved this method of choosing those who should be penalized as reasonable under the circumstances.

More often if the discipline is challenged in arbitration, the employer will have the burden of proving that these men were actually more deserving of punishment than the other participants. ${ }^{91}$ This idea is illustrated by a statement from an opinion of Whitley P. McCoy:

sent grievances to their employer and to have such grievances adjusted, without the intervention of the bargaining representative, as long as the adjustment is not inconsistent with the terms of a collective bargaining contract or agreement then in effect; Provided further, That the bargaining representative has been given opportunity to be present at such adjustment."

86. See Individual Grievances 53-54.

87. Arsenault v. General Elec. Co., 20 Conn. Supp. 413, 137 A.2d 762 (Super. Ct. 1957); see Lenhoff, The Effect of Labor Arbitration Clauses Upon the Individual, 9 ARB. J. (n.s.) 3, 8-9 (1954). Even were he able to force arbitration, it is unlikely that an individual would be able to bear half the cost of the process.

88. The union may also be under pressure to end an unauthorized walkout. Even if it is not liable in damages, a non-bargaining-agent strike may shake the employer's confidence in the union.

89. International Harvester Co., 21 Lab. Arb. 239 (H. H. Platt 1953) ; cf. NLRB v. American Mfg. Co., 203 F.2d 212 (5th Cir. 1953) (Employer did not commit an unfair labor practice when it rehired all but twelve of the strikers; no discussion that these were more guilty than others.).

90. 27 Lab. Arb. 321 (P. N. Lehoczky 1956).

91. McLouth Steel Corp., 24 Lab. Arb. 761 (G. E. Bowles 1955); Chrysler Corp., 17 Lab. Arb. 814 (D. A. Wolff 1952). But see George Groton Mach. Co., CBNC 
"In a case of this kind, especially in view of the no-strike clause of the contract, it is generally held that the Company may discipline all who walk out, but it must treat all charged with the same offense alike. If it chooses not to discipline all who walk out, but only the leaders, it must prove leadership, and the discipline imposed must bear a fair relationship to the degree of guilt. It cannot, for want of proof, merely pick out some to set an example to others. Nor may it pick out those who, because of prior incidents, it feels morally certain must have instigated the trouble." 92

And unlike those cases where the arbitrator feels the penalty is too severe and reduces it, if the employer is unable to prove a reasonable basis for the distribution in punishment the arbitrator will strike out the distinction completely, and the employer may have his right to punish for the stoppage completely foreclosed. ${ }^{93}$ Therefore, it is important to consider some of the distinctions which arbitrators have held to be permissible.

\section{A. Incitement or Maintenance}

Where the company is able to prove that the disciplined employees engaged in strike violence, distinction in penalties will be upheld. ${ }^{94}$ It is also clear that a greater penalty can be assessed against employees who organize a stoppage or try to convince others to join it, ${ }^{95}$ and against employees who spread the stoppage by notifying others of it. ${ }^{96}$ One case which touches on several of these considerations is Oronite Chemical Co.97 The production worker involved could not start work until chemicals were brought to him. Since the porter was not in the area, his foreman asked him to bring the chemicals in himself. Although this would not have involved arduous work, the employee told the foreman that such work was not in his job description and refused to get the chemicals. The foreman told him to get them or leave. The employee, who was himself a shop steward, got in touch with the president of the local and with the inter-

$77: 325,327$ (machinists contract, in which the union agrees to "leave the company free to discipline (including discharge) any employee involved, without necessarily disciplining all employees so involved; and such action shall not be held to be discriminatory.").

92. Rheem Mfg. Co., 8 Lab. Arb. 85, 87 (1947) ; see International Harvester Co., 16 Lab. Arb. 695 (R. T. Seward 1951).

93. Aurora Gasoline Co., 29 Lab. Arb. 495 (R. G. Howlett 1957). But see International Minerals \& Chemical Corp., 28 Lab. Arb. 121 (A. R. Marshall 1956) (no proof of incitement; two-week layoff reduced to one week).

94. Southern Bell Tel. \& Tel. Co., 25 Lab. Arb. 767 (C. R. Schedler 1956); cf. Administrative Ruling of Gen. Counsel, Case F-253, CCH LAB. CAs. If 55,128 (1958).

95. H. J. Heinz Co., 16 Lab. Arb. 664 (P. N. Lehoczky 1951) ; Fern Shoe Co., 14 Lab. Arb. 268 (J. A. C. Grant 1950); $c f$. Borg-Warner Corp., 4 Lab. Arb. 4 (C. M. Updegraff 1945).

96. Hawaiian Agricultural Co., 29 Lab. Arb. 142 (H. S. Burr 1957) (Strikers from main plant visited outlying fields, after which workers there walked out.); Underwood Glass Co., 27 Lab. Arb. 614 (J. M. Klamon 1956) (Foreman tried to get a few workers to stay overtime to avoid work cessation while strike was being settled; grievant followed foreman and advised workers to refuse to work overtime.).

97. 20 Lab. Arb. 875 (A. E. Ralston, Jr. 1953). 
national, and was advised to use his own judgment. The employee told every man on his shift that he was being sent home and when he left the whole shift went with him. The company, in compliance with the contract, notified the local and the international, and discharged the employee the next day. The arbitrator upheld the discharge, finding a duty to carry the complaint through the grievance procedure rather than walking out, and that the only reason for notifying the other employees must have been to get their support in whatever action he took. ${ }^{98}$

\section{B. Past Record}

Some contracts appear to make incitement or maintenance the only criteria by which inequality can be justified. ${ }^{99}$ Others make a distinction between employees who have previously been guilty of participation in a stoppage and those who have not. ${ }^{100}$ In the absence of such clauses, most arbitrators rule that the employer can take into account any past occurrence for which the employee could have been punished without violating the seniority clause of the contract. ${ }^{101}$ However, a growing group of arbitrators limits the use of past record to recent offenses. This latter view is based on the following reasoning:

"A penalty for any given act should be directed at that act and should not normally take into account an accumulation of diverse misdemeanors. To paraphrase this, employees should not be discharged for a work stoppage when in fact they are being discharged because of an absentee record, or poor workmanship, or any one or more of a number of other shortcomings. . . ." 102

Modern ideas of corrective rather than punitive industrial discipline support this latter view. Yet the employer should have some way to cumulate certain offenses where the employee is a continual troublemaker. It would appear that the best approach would be to allow the employer to consider those offenses for which the employee has been warned, either by notice and notation on his record or by actual punishment. In this way, the

98. See also American Brake Shoe Co., 13 Lab. Arb. 294, 312 (J. D. Larkin 1949): "A word from Kelly might have put the men back to work at any time during the three weeks' strike. All he needed to do was to urge the men to return to work and to say that his grievance would be taken up as provided [by the contract]. ..." (Kelly was a union leader who had been discharged.)

99. Johns-Manville-Federal Labor Union, AFL, contract, CBNC $77: 301$ : "[S] uch discipline as the company shall determine his degree of participation warrants."

100. Babcock \& Wilcox Co., 29 Lab. Arb. 681 (H. J. Dworkin 1957) ; JohnsManville Corp.-Federal Labor'Union, AFL, contract, CBNC $77: 301$.

101. Wesson Oil \& Snowdrift Co., 29 Lab. Arb. 629 (P. M. Kelliher 1957); Borg-Warner Corp, 22 Lab. Arb. 589 (J. D. Larkin 1954).

102. Glass Container Manufacturers Institute, 27 Lab. Arb. 131, 133 (P. N. Lehoczky 1956); see Aleo Mfg. Co., 15. Lab. Arb. 715 (S. H. Jaffe 1950), enforcement granted sub nom. Textile Workers Union, CIO v. Aleo Mfg. Co., 94 F. Supp. 626 (M.D.N.C. 1950). 
employee will have been given an opportunity to correct his attitude toward his job. In addition, if the distinction is challenged the employer will be able to support it in arbitration with the real evidence of the employee's record.

\section{Union Leaders}

When inequality of treatment results in greater penalty for union leaders than for the remainder of the participants in the work stoppage, the employer enters an area where arbitrators are in great disagreement. It is clear that where a union leader instigates or incites a stoppage, he is liable to greater punishment in the same way as those not holding office ${ }^{103}$ -the fact that he is a union leader does not absolve him from punishment for a violation of the contract. But his union leadership in and of itself is not proof that he had a larger part in instigating the strike than others. ${ }^{10 *}$

The real area of conflict centers on the issue of whether a union leader has a greater responsibility to the employer than an ordinary employee. In a few contracts, this issue is foreclosed. For example, the contract between the Newport Steel Company and the Steelworkers Union reads as follows:

"The right of the Company to discipline an employee for violation of this Agreement shall be limited to the failure of such employee to discharge his responsibilities as an employee and may not in any way be based upon the failure of such employee to discharge his responsibilities as a representative or officer of the Union." 105

Unless it could be argued that only the union leaders are familiar with the no-strike clause, such a provision would preclude discrimination against union leaders qua union leaders for a work stoppage.

In the absence of a contract clause bearing on the issue, some arbitrators would require the union leaders to take positive action toward counselling the employees to avoid the stoppage or return to work. ${ }^{106}$ In

103. International Harvester Co., 13 Lab. Arb. 610 (W. W. Wirtz 1949); cf. Michigan Lumber Fabricators, Inc., 111 N.L.R.B. 579 (1955).

104. Babcock \& Wilcox Co., 29 Lab. Arb. 681 (H. J. Dworkin 1957) ; Aurora Gasoline Co., 29 Lab. Arb. 495 (R. G. Howlett 1957). But cf. Bower Roller Bearing Co., 22 Iab. Arb. 320 (G. E. Bowles 1954) (steward's position of respect used as circumstantial evidence of incitement); International Harvester $\mathrm{C}_{0}$., $21 \mathrm{Lab}$. Arb. 239 (H. H. Platt 1953) (employer upheld in firing union leaders who were among those distributing leaflets, since they were the only ones familiar to its representative).

105. CBNC $77: 302-03$.

106. Skenandoa Rayon Corp., 21 Lab. Arb. 421 (I. R. Feinberg 1953) ; Ford Motor Co., Opinion A-153 (H. Shulman 1944), in Shulman \& Chamberdain, Labor ReraTIONS 432, 434 (1949) : "It is not a breach of loyalty to his men to insist that they perform their duties and bring no reproach upon their union. Indeed, true loyalty to his men, as well as to his union and to the contract, requires [the committeeman] to do just that; and to do it at the very time when his men are disinclined to heed his advice. When his men are bent on a wildcat strike and picketing violative of the contract ... his duty is to continue his efforts to dissuade them. If he fails to do this, he is at least not to join them and give them leadership." 
International Harvester $\mathrm{Co}^{107}$ a new contract entered into after a long and costly strike made certain changes which resulted in less benefits for the employees. After three months the employees decided that the employer was not acting in good faith on their gievances and authorized a strike. One morning before the day shift arrived, several employees stood in front of the plant handing out leaflets and urging employees to attend a meeting to be held that afternoon, on company time. The company tried to get the union leaders among them to aid in heading off the stoppage. When they refused, six were discharged-the union president, vice president, a steward and two committeemen. This action was upheld by the arbitrator. Although others participated in handing out leaflets, these were the only ones with whom the representatives of the employer were sufficiently familiar to identify. In addition, it was held that these respected union leaders had a responsibility to enforce compliance with their contract, and other participants had neither the authority nor the responsibility to do what the aggrieved were expected to do. Although this view appears to be among the majority, it is not universally held. ${ }^{108}$

Also in the majority are those arbitrators who hold union leaders to a duty to remain on the job when the rest of the employees walk out. ${ }^{109}$ In Ross Gear \& Tool Co. ${ }^{110}$ the employer unilaterally changed the incentive rate in one department. The employees were dissatisfied with the new rate and threatened a walkout. Three shop stewards tried to get in touch with the international representative to head off the strike but when this failed they walked out with the men. All three were given two-week suspensions whereas none of the other participants got any punishment. This distinction was upheld by Pearce Davis, who said, "Local union officials are bound, by virtue of their office, to set personal examples of opposition to contract violation. They cannot be passive; they must vigorously seek to prevent contract violations by their constituents." 111 Only a few cases have held that a union leader's duty is over once he tries to convince the men to remain on the job and that if they persist in the walkout, he may join them without subjecting himself to greater penalties than the rest of the strikers. ${ }^{112}$

Some distinction between union leaders and the remainder of the working force seems justified. As has been said above ${ }^{113}$ a union leader

107. 21 Lab. Arb. 239 (H. H. Platt 1953).

108. Bower Roller Bearing Co., 22 Lab. Arb. 320 (G. E. Bowles 1954); International Harvester Co., 15 Lab. Arb. 75 (R. T. Seward 1950).

109. Bethlehem Pac. Coast Steel Corp., 28 Lab. Arb. 369 (A. C. Miller 1957); Ford Motor Co., $6 \mathrm{Lab}$. Arb. 799 (H. Shulman 1947): "The strikers here should have been told plainly that it was their duty to all to stay on their jobs, ... and the only way to make such instructions meaningful is to have other employees, particularly union representatives, do the work when the instructions are not heeded. That is not scabbing or acting like a heel. It is honorable and courageous leadership in the performance of a moral and legal duty...."

110. $28 \mathrm{Lab}$. Arb. 782 (1957).

111. Id. at 791 .

112. Aurora Gasoline Co., 29 Lab. Arb. 495 (R. G. Howlett 1957) ; Borg-Warner Corp., 4 Lab. Arb. 4 (C. M. Updegraff 1945).

113. See text at note 80 sipra. 
who has a grievance has a higher obligation to seek redress through the contractual procedure because he has sure access to and control over the grievance procedure and because he is an agent of a group whose integrity is injured by a breach of the contract. On the other hand, when the protagonist in the dispute is someone other than the union leader himself the extent to which the union leader's duty differs from that of other employees should be subject to greater limitations.

If every union leader worked actively to head off a strike by attempting to convince the workers that such a breach of their contractual obligation is not to their best interests and by emphasizing the agreed-upon grievance procedures, and refused to walk out with them, it is unlikely that the strike would get past the talking stage.114 An employer could best achieve this result were he permitted to lay heavier penalties on any union officers who participate in any way in the stoppage. But if the extra duty is made unreasonably high, the employer might be provided with an excuse for discharging any union officers whom he feels have been uncooperative. It might also act as a deterrent to a workman's trying to become a union leader, since by doing so he would run the risk of greater penalties if a work stoppage were to occur.

In light of these considerations it would seem that where a dispute arises which threatens to precipitate a work stoppage in violation of the contract, the only duties of a union leader ought to be to inform the disputant about the grievance machinery and try to induce him to use it, and to notify the higher authorities within the local and the international with an eye towards settling the dispute peaceably. If he fails in these he is deserving greater penalties. If the workmen insist on striking, the union leader ought to have no more duty to remain on the job than any other worker. To ask him to do so is to run against human nature. H. M. Teaf has phrased it this way:

"The arbitrator believes that it is expecting too much of an ordinary human being, even if a Union official, under the compulsions that always exist in group relations (even where there is no binding element such as Union membership) and under pressures for social esteem of his fellows, to ask that he take a course different from that of the group. These compulsions are all the more powerful when emotions are aroused, as they must have been in the present case not long after the sitdown started. [As a steward put it], he would have separated himself from the rest of the employees had he returned to his bench." 115

It might be suggested that even where the union leader fails in these duties punishment ought to flow from the union and not from the employer. Every employee has a duty to the employer not to participate in work

114. See Bethlehem Pac. Coast Steel Corp., 28 Lab. Arb. 369 (A. C. Miller 1957); American Brake Shoe Co., 13 Lab. Arb. 294 (J. D. Larkin 1949).

115. C \& D Batteries, Inc., 16 Lab. Arb. 198, 208 (1951). 
stoppages. As a union leader the employee's extra duties are to the members of the union-to maintain the union's reputation for integrity to the contract and to try to discourage activities which might subject his men to discipline. It is the union, and not the employer, which is directly injured when the leader is derelict in this duty. It is recognized, however, that since arbitrators have so generally permitted employer discipline on these matters it would be inequitable to withdraw this power without notice. The economic loss suffered by employers whose disciplinary punishments are overturned in arbitration can ofttimes be serious, e.g., reinstatement with back pay after loss of production from the employee during a period of dismissal or suspension. The most desirable solution would be for the contract to provide for union punishment of dereliction by union leaders upon the employer's petition. 110 This solution is actually favorable to employers in that the union is able to use a greater range of penalties than the employer, including the meaningful one of a fine. In addition, the recipient of discipline from the employer is often able to enlist the sympathy and support of other workers in a further stoppage. If the discipline is meted out by the union, other employees are more likely to respect it. Of course, if such a procedure is to be effective, there would have to be some method of the employer's challenging the punishment through grievance and arbitration, if it considers the punishment insufficient.

\section{Summary and Conclusions}

At the end of a work stoppage, the employer is most interested in getting the men back to work as quickly and quietly as possible and doing all he can to avoid such stoppages in the future. If the stoppage was unprotected the employer may find penalizing the employees who participated in it is the best way to reach these two aims. The employer must follow the procedures set out in the contract and, if its action is subject to challenge under the grievance procedure, must see that the imposed penalties reflect various considerations. Because of the difference in the standards of individual arbitrators, it is impossible to make a categorical evaluation of the factors which must influence the employer's determination. However, if the employer makes a conscientious effort to consider the gravity of the stoppage the underlying cause of the dispute, and to distinguish in penalties between individual employees only on proper grounds, it will achieve a sanction which will not unduly prejudice labor-management relations and which will be sustained by most arbitrators.

M.S.E.

116. Cf. text at note 47 supra. 